UDC 070 - 051: [005.57:614.8]

https://doi.org/10.23939/sjs2019.01.011

Bozhena Ivanytska, Ihor Onyskiv

Doctor $\mathrm{PhD}$ of social communication,

Lviv Polytechnic National University,

Department of journalism and mass communication,

bozhena.v.ivanytska@lpnu.ua

\title{
THE ROLE OF JOURNALISTS IN INFORMING SOCIETY ABOUT EXTRAORDINARY EVENTS
}

\section{(C) Ivanytska Bozhena, Onyskiv Ihor, 2019}

The role of a military journalist in wartime is the collection and operational transmission of information on the situation at the front. A journalist is not a military one, he should not take part in the war.

Every year, the need for professionally trained military journalists is growing. In the context of conducting hostilities in many parts of the world, the information space suffers from false war and information warfare. Also, the lack of qualified journalists is the reason for the lack of objective and operational information. So, there are only a few universities in Ukraine that have small theoretical training courses for future military journalists.

Presentation of the main research material. If a journalist, after everyday work, goes to the places of hostilities and wears a uniform, he immediately understands his role - to show the situation from the inside. Quite often, military journalists have to deal with the opposite side of the conflict. Enemies themselves can seek and connect with journalists in order to show everything to their side. These can be notes, telephone conversations or video interviews. Such a tendency was observed during the war in Iraq, where terrorists went to Baghdad journalists and asked to record video conversations for the other party. Thus, civilians can hear both sides, their dissatisfaction and the demands of the conflict. At such moments, there is a perilous fear of life and, at the same time, pride due to the trust of journalists on both sides.

By satisfying the public's need for information, the media automatically assumes responsibility for the ethical standards of all published materials. One of the problems of all military journalism is that the journalist should always be impartial and objective, but if you talk to soldiers and feel their emotions, you eat together with one pot, sleep together, then it's difficult to remain immortal and objective. Though the journalist's profession involves illumination of dry facts, after such a stay in places of armed conflict, the journalist transmits information through the prism of his own reflections and emotions. It is important not to cross the threshold of ethics in such cases, because incorrect information leads to serious consequences.

Key words: extreme journalism, emergency situations, journalism, ethical norms.

Божена Іваницька, Ігор Ониськів канд. наук із соц. ком., асистент кафедри ЖЗМК, Національний університет “Львівська політехніка"

\section{РОЛЬ ЖУРНАЛІСТІВ У ІНФОРМУВАННІ СУСПІЛЬСТВА ПРО НАДЗВИЧАЙНІ ПОДІї}

Задовольняючи потребу суспільства в інформації, ЗМІ автоматично бере на себе відповідальність за етичні норми всіх опублікованих матеріалів. Серед екстремальних умов діяльності журналіста окремим видом можна назвати надзвичайні ситуації. 
Питання їх висвітлення не менш важливе, адже стихійні лиха, техногенні катастрофи та й менш масштабні надзвичайні ситуації впливають на життя суспільства. Згідно 3 результатами дослідження Української академії преси "Моніторинг політичних новин" за участю працівників Інституту соціології Національної академії наук України, у червні 2018 р. найбільше уваги в українському телевізійному просторі приділяли власне цій тематиці - близько $18 \%$. Такі трагедії забирають життя сотень та навіть тисяч людей, позбавляють їх помешкання та комфортного життя, змушують шукати притулку. Часто різні події, катастрофи потребують швидкого реагування та інформування суспільства, для якого це може бути важливим. Журналістам, які працюють в таких екстремальних умовах, необхідно докласти всіх зусиль не тільки для повідомлення про катастрофу, а й для професійного викладення важливих вказівок, щоб запобігти трагічним наслідкам. Саме завдяки екстремальним журналістам ми можемо швидко зреагувати й убезпечити себе.

Екстремальна журналістика - це першоджерело новин, 3 якого світ дізнасться про останні надзвичайні події та трагедії. Роль журналіста полягас в оперативному збиранні інформації про подію, яка трапилась, і швидкому передаванні цієї інформації в суспільство. Екстремальна ситуація, як і робота на війні, вимагас максимального зосередження на події, об'сктивності та достовірності. Адже журналіст теж людина, якій притаманні емоції, та, попри них, він повинен залишитись об'єктивним у своїх публікаціях. Саме тому екстремальним журналістам більше довіряють, бо вони були в місці надзвичайної події та бачили все на свої очі, тож можуть точно констатувати факт і всі деталі трагедії.

Ключові слова: екстремальна журналістика, надзвичайні ситуації, журналістика, етичні норми.

It is worth noting the special difficulty of collecting information and its dissemination through military secrets: it is forbidden to display the military faces, demonstrate their number and number of available equipment and weapons, disseminate their positions and much more. The military journalist must have a proper approach to the military and act as a not only microphone or camera holder, but also the transmitter, the socalled bridge, between the military and civilians. Thus, security agencies have close contact with media representatives who work in a military environment and control the entire information space.

The coverage of military operations is often associated with negative consequences, as journalists, often without knowing it themselves, hurt one of the parties. Given the availability of information reception media, unnecessary information can be very negative for society. One of those situations was the seizure of 33 hostages at a college in Berkeley. Reporters unknowingly showed live broadcast of all actions aimed at the release of the captives at a time when the terrorists were watching over the TV. This led to the shooting of one hostage. Later, one of the emancipated commented on this situation: "While we were following with the terrorist for the reports transmitted on your channel, we just could not believe their eyes and ears. Your unscrupulous and negative comments not only infuriated the perpetrator - they endangered the lives of 33 people. Your transmissions caused new threats of violence, which no serious station was supposed to allow. "Military reporters need to be clear about their responsibility and the moral burden of such reckless actions and to be more careful and sensitive about the events.

Summing up, several aspects of the work of military journalists can be distinguished: operational coverage of military operations, events on the lines of contact and "hot spots"; the proper interaction with the security services and the military; awareness of disseminated information and careful and careful selection of it; own safety of life in conditions of armed conflict.

In addition to classification by origin, they can also be divided into the extent to which they are distributed and the losses that they were asked: object level, local level, regional level, national level, global level. As a rule, the primary sources of all emergencies are man-made. On a local scale, they can grow to global, for example: the need for nutrition - the creation of agriculture - the 
processing of the food industry - global warming. Thus, any minimal carelessness or unreasonable need can lead to inevitable consequences.

Among the extreme conditions of a journalist's work, one can see the exceptional situation. The issue of their coverage is equally important, as natural disasters, man-made disasters and smaller emergencies affect the life of society. According to a study by the Ukrainian Academy of Press "Monitoring Political News" with the participation of the Institute of Sociology of the National Academy of Sciences of Ukraine, as of June 2018, the most attention in the Ukrainian television space is paid to this topic - about $18 \%$. Tragedies of this nature take lives of hundreds and even thousands of people, deprive them of their homes and comfortable lives, forcing them to seek asylum. Because of the frequent events of various catastrophes, there is a need for quick response to them and for informing the society for which it may be important. Journalists working in such extreme conditions need to make every effort and professionalism not only to report a disaster, but also to provide important guidance that would prevent tragic consequences. It is thanks to extreme journalists that we can quickly react and secure ourselves.

Extreme journalism is the primary source of news from which the world learns about the latest emergencies and tragedies. The role of the journalist consists in the operational collection of information about the event that happened, and the rapid transfer of this information to society. The extreme situation, as well as work in the war, requires maximum concentration on events, objectivity and reliability. After all, the journalist is also a man and he has emotions and, in spite of them, he should remain immutable in his publications. That is why extreme journalists are more confident because they were in a place of emergency and saw everything in their eyes, so they can accurately state the fact and all the details of the tragedy.

In the work of an extreme journalist, there is another aspect - an emergency can not be scheduled and the reporter should be directed in advance with a plan of pre-designed actions. In such circumstances, journalists have to fulfill their professional duties already after an event has occurred. The main thing in this is the coverage of the event, not its reproduction.

The case of an extreme journalist is not to wear a body armor and a white helmets with the inscription "PRESS". First of all, it is the coverage of events directly from the place where it takes place, which civil journalists do not have access to. This is not only a show of "dramatic picture", but also many interviews with soldiers, rescuers, victims, reporting from hot spots, fixing and spreading events. The difficulty of such work is complicated by the constant threat to journalist's life.

One of the aspects of analyzing journalistic activity in extreme conditions is the study in the context of the psychological qualities of a journalist's personality. Scientists have found that various extreme situations activate absolutely different psychological qualities. Therefore, for a journalist who works in extreme conditions, all positive psychological qualities are needed, such as: high stress tolerance, emotional and volitional resistance, ability to justify risk, courage, ensuring professional success in dangerous situations. In the absence or lack of development of these psychological qualities for a journalist, this may turn into a nerve disorder and psychosomatic illness.

An unfavorable factor in the activities of the journalist is an uncertain psychological state in which it is difficult for him to determine his thoughts and to submit information correctly. There are two states of voltage: the voltage, which has the effect of mobilizing the journalist and is positive, and the tension that reduces the psychological stability of the journalist until the disintegration of the activity and is negative. In addition, the tension of a journalist in extreme conditions is divided into perceptual, intellectual, emotional, motivational, volitional.

There is a fairly new method of training activities in unpredictable situations and keeping people calm in such conditions - "Shocotherapy". A method in which a person is introduced in realistic-simulated situations in which he had never been before, and tightened it thus in adverse and unpredictable conditions. According to this method, a person acquires the features of resistance to unforeseen situations and remains in peace, which helps him to take rational and decisive action. Thus, the form of behavior in extreme situations varies from active / passive-emotional to expedient-active. This method often selects in the structure of a special response or astronauts-discoverers, etc., which removes among thousands of those who want the most stable individuals. The method also has a negative impact on this selection, because those who have not been able to withstand severe adverse conditions and have undergone an impulsive 
form of behavior often postpone psychological pressure that requires rehabilitation. It should be emphasized that shock therapy has recently been used in a completely different way - in promoting the useful actions of the population, which can be used to fight crime and hatred, harmful traits of people or charity, etc. An example of such a method is the terrible photos of human organs that portray health effects on cigarette packs or the emotional photos of poor African children on water bottles that motivate the purchase to attract funds from each bottle to overcome drought and hunger. Thus, shock therapy informs people, promotes a certain problem, shockingly depicts and motivates certain actions.

\section{REFERENCES}

1. Aronson E. Age of propaganda: the mechanisms of persuasion / E. Aronson. - St. Petersburg : Prime-Euroznak, 2001. - 384 p. 2. Artamonova I. M. Trends in Development and Perspectives of Internet Journalism in Ukraine: monograph / I. M. Artamonov. - Donetsk: Swan, 2009. - 416 p. 3. Berezin V. M. Mass communication: essence, channels, actions / V. M. Berezin. - M. : Rich-Holding, 2003. - 174 p. 4. The Law of Ukraine on the Basic Principles of Information Society Development in Ukraine for 20072015, No. 537-V // www.rada.gov.ua 5. Law of Ukraine on the procedure for coverage of activities of state authorities and local self-government bodies in Ukraine by mass media. No. 539/97-BP with changes // www.rada.gov.ua 6. Mass media in the activity of state authorities and local self-government: Teaching method. manual / Formation. V. M. Draspack. - D. : DF UADU, 2000. - 48 s. 24 7. Information and analytical support of strategic management // http://www.vuzlib.net/strat_upr/54.htm 8. Litvinenko O. Special informational operations and propaganda campaigns / O. V. Litvinenko. - K., 2000. 9. Moskalenko A. S., Gubersky L.V., Ivanov V.F. Basics of mass information activity: textbook. - K., 1999. 10. Pocheptsov G. G. Modern information wars / G. G. Pocheptsov. - K. : Publishing House "Kyiv-Mohyla Academy", 2015. 497 p. 11. Tactics of radio troops. Course of lectures // Ed. Yu I. Rafalsky. - Kharkiv : Kharkiv University of Air Forces, 2005. - 117 p. 12. Tkachenko V. I., Danik Yu. G., Drobakh G. A., Karpenko V. I., Pashchenko R. E., Smirnov E. B. Theory and technique of counteraction to unmanned aerial vehicles. Application and prospects of development. Detection of undetected airborne attacks. - Kharkiv : HVU, 2002. $-220 p$. 